\title{
Effect of heating strategies on whey protein denaturation-Revisited by liquid chromatography quadrupole time-of-flight mass spectrometry
}

\author{
M. Akkerman, ${ }^{*}$ V. M. Rauh, $†$ M. Christensen, $†$ L. B. Johansen, $†$ M. Hammershøj, ${ }^{*}$ and L. B. Larsen*1 \\ *Department of Food Science, Science and Technology, Aarhus University, Blichers Allé 20, DK-8830 Tjele, Denmark \\ †Arla Foods Strategic Innovation Centre, Rørdrumvej 2, DK-8220 Brabrand, Denmark
}

\begin{abstract}
Previous standards in the area of effect of heat treatment processes on milk protein denaturation were based primarily on laboratory-scale analysis and determination of denaturation degrees by, for example, electrophoresis. In this study, whey protein denaturation was revisited by pilot-scale heating strategies and liquid chromatography quadrupole time-of-flight mass spectrometer (LC/MC Q-TOF) analysis. Skim milk was heat treated by the use of 3 heating strategies, namely plate heat exchanger (PHE), tubular heat exchanger (THE), and direct steam injection (DSI), under various heating temperatures $(T)$ and holding times. The effect of heating strategy on the degree of denaturation of $\beta$-lactoglobulin and $\alpha$-lactalbumin was determined using LC/MC Q-TOF of $\mathrm{pH} 4.5$-soluble whey proteins. Furthermore, effect of heating strategy on the rennet-induced coagulation properties was studied by oscillatory rheometry. In addition, rennet-induced coagulation of heat-treated micellar casein concentrate subjected to PHE was studied. For skim milk, the whey protein denaturation increased significantly as $T$ and holding time increased, regardless of heating method. High denaturation degrees were obtained for $T>100^{\circ} \mathrm{C}$ using PHE and THE, whereas DSI resulted in significantly lower denaturation degrees, compared with PHE and THE. Rennet coagulation properties were impaired by increased $T$ and holding time regardless of heating method, although DSI resulted in less impairment compared with PHE and THE. No significant difference was found between THE and PHE for effect on rennet coagulation time, whereas the curd firming rate was significantly larger for THE compared with PHE. Micellar casein concentrate possessed improved rennet
\end{abstract}

Received June 8, 2015.

Accepted September 1, 2015.

${ }^{1}$ Corresponding author: lbl@food.au.dk coagulation properties compared with skim milk receiving equal heat treatment.

Key words: whey protein denaturation, rennetinduced coagulation, indirect heat exchanger, direct heat exchange

\section{INTRODUCTION}

Dannenberg and Kessler (1988) carried out a highly acknowledged study of thermally induced whey protein denaturation. They established relationships for denaturation kinetics of whey proteins in skim milk as function of heat-treatment temperature $(\boldsymbol{T})$ and holding times by use of a laboratory-scale tubular heating system. The reaction kinetics of whey protein denaturation has been studied at the various heating systems, experimental conditions, and analytical methods (Dannenberg and Kessler, 1988; Kessler and Beyer, 1991; Anema and McKenna, 1996; Oldfield et al., 1998b; Anema et al., 2007; Zúñiga et al., 2010; Dissanayake et al., 2013). Various factors were found to influence the denaturation degree of whey proteins. This can be variations in heating conditions and heating systems and variations in the analysis of whey protein denaturation (Oldfield et al., 1998b).

Three widely used heating strategies used in the dairy industry for heat treatment of milk are plate heat exchanger (PHE), tubular heat exchanger (THE), and direct steam injection (DSI). The overall heating system differs between these heating methods. The heat transfer is lower for the indirect heating systems, PHE and THE, compared with direct heating by DSI because of heat exchange occurring through a stainless steel barrier separating milk and steam. Furthermore, indirect heating implies a smaller surface area for heat exchange, larger flow areas, and less turbulence of the milk through the system. Comparing indirect systems, PHE has a higher heat transfer than THE because of corrugation of the plates (Edmond, 2001; Abu-Khader, 2012). Low heating and cooling rates in PHE and THE give longer transit time through the heat exchangers, which makes the fluid more prone to chemical changes 
and fouling (Lewis and Deeth, 2008). Direct steam injection has a short heating time compared with PHE and THE because of injection of steam, which gives fast increase in temperature and use of vacuum to remove water, resulting in faster cooling (Deeth and Datta, 2002). This reduces the risk of chemical changes such as whey protein denaturation (Oldfield et al., 1998b; Lorenzen et al., 2011).

It is well known that heat treatment of milk has a large effect on whey protein structure and properties (Singh and Havea, 2003). The major whey proteins are $\beta$-LG and $\alpha$-LA, which represent 50 and $20 \%$ of the total whey protein content in milk, respectively (Farrell et al., 2004). Heat treatment $>60^{\circ} \mathrm{C}$ results in unfolding of the globular structure of the whey proteins, and they thereby denature (Dannenberg and Kessler, 1988; Kontopidis et al., 2004; Creamer et al., 2011). These nonnative structures can form aggregates with other unfolded monomers or aggregate with other types of protein molecules (Carbonaro et al., 1998; Tolkach and Kulozik, 2007). The main aggregates formed due to heat treatment of milk are complexes of denatured whey proteins, as well as complexes of $\beta-\mathrm{LG}$ and $\kappa$-casein, bound by disulfide bonds, located on the surface of the casein micelles via hydrophobic interactions (Corredig and Dalgleish, 1996; O'Connell and Fox, 2011). In relation to dairy products, heat treatment of milk at high temperatures causes increased rennet-induced coagulation time and lower curd firmness (Waungana et al., 1996). Waungana et al. (1996) observed that heat treatment leading to denaturation degrees $<60 \%$ of $\beta-\mathrm{LG}$ had only small effects on rennet-induced coagulation time of skim milk, whereas gel strength decreased as denaturation increased. Removal of whey proteins from skim milk was found to reduce rennet-induced coagulation time and increase the final gel strength (Pierre et al., 1992; Wang et al., 2007). This supports the theory of whey proteins having a negative effect on the rennetinduced coagulation abilities of milk.

The objective of the present study was to analyze the effect of 3 different heating strategies, PHE, THE, and DSI, in a pilot-plant setup of a matrix of time-temperature conditions on the thermal denaturation of whey proteins in skim milk, as analyzed by liquid chromatography quadrupole time-of-flight mass spectrometer (LC/MS Q-ToF) to revisit results by Dannenberg and Kessler (1988). Furthermore, the resulting rennetinduced coagulation properties of the heat-treated milk were determined by oscillatory rheometry. Finally, for comparison, micellar casein concentrate (MCC) was subjected to heat treatment to study the effect of whey proteins on rennet-induced coagulation.

\section{MATERIALS AND METHODS}

\section{Milk Samples}

For the analyses pasteurized bovine skim milk $\left(72^{\circ} \mathrm{C}\right.$, 15 s) was obtained from Brabrand dairy (Arla Foods, Brabrand, Denmark). The skim milk batches contained 3.47 to $3.79 \%$ protein, 4.75 to $4.88 \%$ lactose, 9.26 to $9.61 \%$ total solids, and less than $0.08 \%$ fat, as determined by Milkoscan FT1 (Foss, Hillerød, Denmark). The $\mathrm{pH}$ values of the milk batches were 6.73 to 6.84 . The MCC was produced from pasteurized skim milk from which approximately $80 \%$ of the whey proteins were removed by microfiltration (Arla Foods Ingredients, Nr. Vium, Denmark). The protein content in $\mathrm{MCC}$ was 3.5 to $3.75 \%$. The casein content in the MCC was thus 10 to $23 \%$ higher compared with skim milk, which contains approximately $80 \%$ casein, whereas mineral, lactose, and TS content was similar to the values for skim milk. Skim milk and MCC, which did not receive any further heat treatment apart from the initial pasteurization, were used as control samples.

\section{Heat Treatments}

A laboratory-scale UHT heat exchanger (PowerPoint International Ltd., Surrey, UK) containing 3 different heating systems was used for heat treatments in the pilot plant at Arla Strategic Innovation Centre (Brabrand, Denmark). The 3 heating methods were THE, PHE, and DSI. The plates and tubes were composed of 5 uniform units, 2 for heating and 3 for cooling. For $T$ $>100^{\circ} \mathrm{C}$, back pressure up to $420 \mathrm{kPa}$ was used to avoid milk evaporation. The PHE contained corrugated flow plates, specialized for this heat exchanger. The tubes in the THE were corrugated tube-in-tube conformation made of stainless steel in a soft spiral pattern with a tube diameter of $8 \mathrm{~mm}$. The passage through one plate or tube unit was approximately $20 \mathrm{~s}$ with a milk flow of $20 \mathrm{~L} / \mathrm{h}$. Preheating temperature for trials with an end point of $T<95^{\circ} \mathrm{C}$ was $60^{\circ} \mathrm{C}$, and a preheating temperature of $75^{\circ} \mathrm{C}$ was applied in trials with end heating point of $T \geq 95^{\circ} \mathrm{C}$. Temperatures between 80 and $140^{\circ} \mathrm{C}$ were used with a desired holding time between 5 and $300 \mathrm{~s}$ by use of 8 -mm-diameter holding tubes of various lengths.

For DSI, the skim milk was preheated by PHE to $75^{\circ} \mathrm{C}$ before entering the DSI system, and cooling was carried out at a flash temperature of $65^{\circ} \mathrm{C}$ by use of vacuum down to $40 \mathrm{kPa}$, followed by a PHE cooling to $4^{\circ} \mathrm{C}$. Heating temperatures between 105 and $145^{\circ} \mathrm{C}$ were applied, using a holding time of $4 \mathrm{~s}$. 
Table 1. Schematic overview of the temperature and holding-time combinations for the 3 heating systems for heat treatment of skim milk ${ }^{1}$

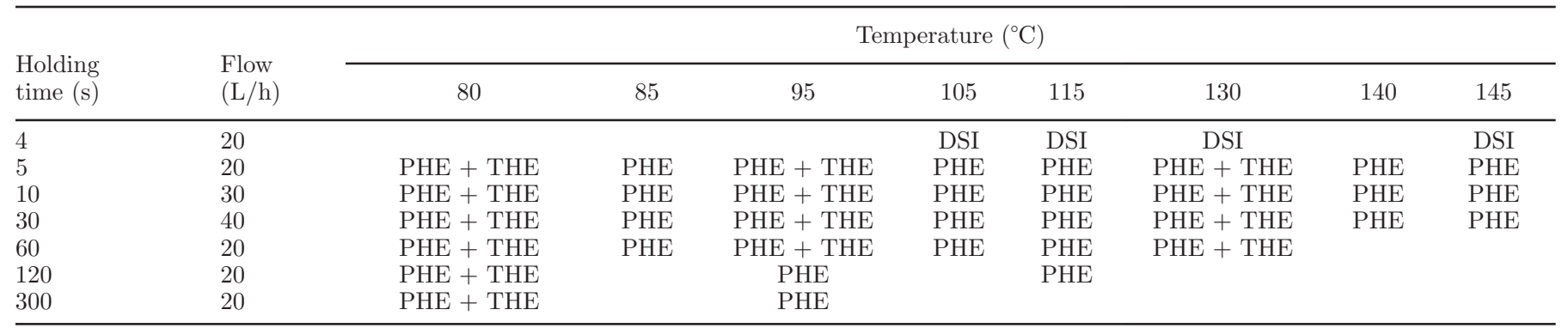

${ }^{1}$ Micellar casein concentrate was only heated by use of PHE with same combinations as for skim milk. PHE $=$ plate heat exchanger; THE $=$ tubular heat exchanger; DSI = direct steam injection.

The $T$ and holding-time combinations for each method and milk type are shown in Table 1. After heat treatment, the milk or MCC was immediately cooled through 3 cooling sections to $T 4^{\circ} \mathrm{C}$.

Each time-temperature combination for all heating systems was performed twice, at 2 different trial days with different batches of milk. One liter of each sample was collected and stored at $4^{\circ} \mathrm{C}$ overnight until further analysis.

\section{Determination of Denaturation Degree of Whey Proteins}

Twenty milliliters of each milk sample was adjusted to $\mathrm{pH} 4.50$ to 4.55 with $1 \mathrm{M} \mathrm{HCl}$ (Merck KGaA, Darmstadt, Germany). The samples were then centrifuged for 10 min at $17,090 \times g$ and $4^{\circ} \mathrm{C}$. The soluble fraction was recovered and kept at $-20^{\circ} \mathrm{C}$ until further analysis. The $\mathrm{pH}$ adjustments were made in duplicates for each milk sample collected. Prior to LC/MS Q-ToF analysis, the thawed samples of $\mathrm{pH} 4.5$-soluble proteins were centrifuged for $10 \mathrm{~min}, 9,300 \times \mathrm{g}$ and $4^{\circ} \mathrm{C}$. This was done to ensure that no insoluble fractions were left in the samples to contaminate the analysis. The soluble fraction was used for analysis.

Whey protein analysis was performed on a LC/MS Q-ToF system consisting of an Agilent 1290 LC infinity system (Agilent Technologies, Santa Clara, CA) and Agilent 6530 Accurate-Mass Q-TOF MS system (Agilent Technologies). The liquid chromatography analysis method was a modification of the model used by Rauh et al. (2014). The samples were kept at $5^{\circ} \mathrm{C}$ in the autosampler. Depending on the protein concentration of the samples, volumes of 5 to $20 \mu \mathrm{L}$ were injected into the LC/MS Q-ToF system. An Xbridge BEH300 (rp-C ${ }_{18}$, $3.5 \mu \mathrm{m}, 2.1 \times 250 \mathrm{~mm}$; Waters, Milford, MA) column was used to separate the components. Mobile phase (A) was $0.05 \%$ trifluoroacetic acid in MilliQ water, and the mobile phase (B) was acetonitrile with $0.1 \%$ trifluoro- acetic acid. Elution conditions were defined by a linear gradient of buffer B in buffer A: 0 to 2 min, 100\% A; 2 to $8 \mathrm{~min}, 17$ to $40 \% \mathrm{~B} ; 8$ to $14 \mathrm{~min}, 40$ to $44 \% \mathrm{~B}$. Flow rate was $0.35 \mathrm{~mL} / \mathrm{min}$. The column $T$ was $45^{\circ} \mathrm{C}$. The $\mathrm{UV}$ at $214 \mathrm{~nm}$ was used for detection.

Mass spectrometry detection was used to identify the whey proteins following the model used by Rauh et al. (2014). Mass scans were continuously recorded to detect components with a mass-to-charge ratio $(\mathrm{m} / \mathrm{z})$ between 300 and 3,200 with resolution of 20,000 in positive node. The Q-ToF-MS used stealth gas of $350^{\circ} \mathrm{C}$ with a flow of $8 \mathrm{~L} / \mathrm{min}$ and a drying gas of $325^{\circ} \mathrm{C}$ at a flow rate of $10 \mathrm{~L} / \mathrm{min}$. A nozzle voltage of $100 \mathrm{~V}$ was used, and the capillary voltage was set to $2,500 \mathrm{~V}$. Data analysis of mass spectrometry data was performed by using Mass Hunter version 06.00 with BioConfirm (Agilent Technologies).

Peaks for $\alpha$-LA, $\beta$-LG B, and $\beta$-LG A were identified from mass spectrometry data, and peak areas from liquid chromatography UV spectra were integrated for each whey protein in all samples. The denaturation degree was defined as the percentage decrease of the whey proteins in $\mathrm{pH}$ 4.5-soluble protein analysis for the heat-treated samples compared with control samples.

\section{Rheological Analyses of Rennet Coagulation}

The analysis of rennet-induced coagulation properties of milk was performed using a ReoRox G2 Rheometer (Medirox, Nyköping, Sweden) on cold-stored samples $1 \mathrm{~d}$ after heat treatment. The oscillation frequency for this equipment is fixed at $10 \mathrm{~Hz}$ and amplitude of $2^{\circ}$, which means that the rheometer sample cup is swung $2^{\circ}$ for each $2.5 \mathrm{~s}$. This gives a corresponding strain of 0.02 , which is within the linear viscoelastic region for standard milk (Andersen, 2013). The analysis was performed as described by Frederiksen et al. (2011). A total of $103 \mathrm{~g}$ of milk was used for each analysis. Initial $\mathrm{pH}$ was noted for all milk samples and adjusted 
to $\mathrm{pH} 6.5 \pm 0.02$ with $10 \%$ lactic acid to avoid the effect of $\mathrm{pH}$ on the rennet-induced coagulation. The milk samples were incubated in water bath at $33^{\circ} \mathrm{C}$ for 30 min. The chymosin type Chy-Max Extra (Chr. Hansen, Hørsholm, Denmark) was added to the milk to a final concentration of 0.038 international milk clotting units (IMCU)/mL of milk. Chy-Max Extra from the same batch was used for all samples. The addition of chymosin is defined as the starting point for the ReoRox analysis. A volume of $1 \mathrm{~mL}$ of the milk sample was transferred to a rheometer sample cup placed in the ReoRox. The rheological measurements collected were clot onset time, rennet coagulation time (RCT), and curd firming rate (CFR). The measurements were performed at $33^{\circ} \mathrm{C}$ for $2 \mathrm{~h}$. All milk samples were measured in duplicates. The relative change in rennet-induced coagulation properties from the corresponding control sample was determined for all heat-treated samples.

\section{Determination of Whey Protein Denaturation Kinetics and Statistical Analysis}

The kinetics of whey protein denaturation reactions were determined based on the general rate

$$
{\frac{C_{0}}{C_{t}}}^{1-n}=1+(n-1) k t,
$$

where $C_{0}$ and $C_{t}$ are the denaturation degrees at control and a specific heating condition, respectively, $t$ is the holding time (s), and $k$ is the rate constant at the given temperature. The reaction order $(n)$ was determined on the basis of results achieved by Dannenberg and Kessler (1988). Reaction order of 1.5 was used for $\beta-L G$, and reaction order of 1 as used for $\alpha$-LA. The rate constants $(k)$ were used to determine the activation energy $\left(E_{\mathrm{a}}\right)$ by a transcription of the Arrhenius equation

$$
\ln (k)=\ln \left(k_{0}\right)-\frac{E_{\mathrm{a}}}{R} \cdot \frac{1}{T},
$$

where $R$ is the universal gas constant $(8,831$ $\left.\mathrm{J} \cdot \mathrm{mol}^{-1} \cdot \mathrm{K}^{-1}\right)$. Least squares means were calculated for all temperature $(T)$ and holding-time combinations for all methods to adjust for variations in samples between combinations. This was carried out for both denaturation- and rennet-induced coagulation data. Two-way ANOVA and 3-way ANOVA were performed to determine significant differences $(P<0.05)$ among samples at different heating temperatures, holding times, and heating methods. This was carried by use of SAS software program version 9.2 (SAS Institute Inc., Cary, $\mathrm{NC})$.

\section{RESULTS AND DISCUSSION}

In this study, 3 different types of heating methods were employed on samples of both skim milk and MCC, with varying whey protein and casein content. The samples were examined for denaturation degree of the major whey proteins, $\alpha-\mathrm{LA}$ and $\beta-\mathrm{LG}$, as a function of heat treatment. These results were discussed in relation to Dannenberg and Kessler (1988). Furthermore, the resulting rennet-induced coagulation properties were determined. The MCC samples were used to examine the effect of denatured whey protein on the rennet coagulation properties. From an industrial perspective, it is of great interest to know how the denaturation degree of whey proteins is affected by heating strategy using pilot-scale heating systems, where a matrix of holding time and temperature conditions can be explored. This allows mimicking of the industrially used heating systems and thereby potentially enables transfer of knowledge achieved at pilot-scale systems to the heating systems at production sites.

\section{Whey Protein Denaturation by Indirect Heating}

Chromatograms of LC/MS Q-ToF analyses of $\mathrm{pH}$ 4.5-soluble whey protein fractions from skim milk heat treated by PHE are shown in Figure 1. From the integration results of UV $214 \mathrm{~nm}$, it is possible to calculate and compare the relative content of $\mathrm{pH}$ 4.5-soluble whey proteins of heat-treated versus control samples. Overall, it is clear that the peak areas of the whey proteins in Figure 1 (peaks 1-3) decrease as the temperature increases, which indicates an increased denaturation of whey proteins. These results are consistent with previous findings (Dannenberg and Kessler, 1988).

The LC/MS Q-ToF analysis of the $\mathrm{pH}$ 4.5-soluble proteins was used to compare the degree of whey protein denaturation by heat treatments using THE and PHE at the various temperatures and holding times. Figure 2 shows the denaturation degree of $\beta-L G$ B and $\alpha-\mathrm{LA}$ in skim milk heat treated using PHE and THE. The denaturation of $\beta$-LG A showed similar pattern as $\beta$-LG $\mathrm{B}$ in denaturation, and the results are therefore not shown graphically. The denaturation degrees of $\beta$-LG A were used further on for reaction kinetics and calculations.

For all whey proteins, a significant increase in denaturation degree was observed when increasing the holding time for all temperatures $(P<0.001)$. The interaction between temperature and holding time was also found to be significant $(P<0.001)$. Increase in temperature at a fixed holding time is seen to give rise to larger increase in denaturation, compared with increasing the holding time at a fixed temperature. This 


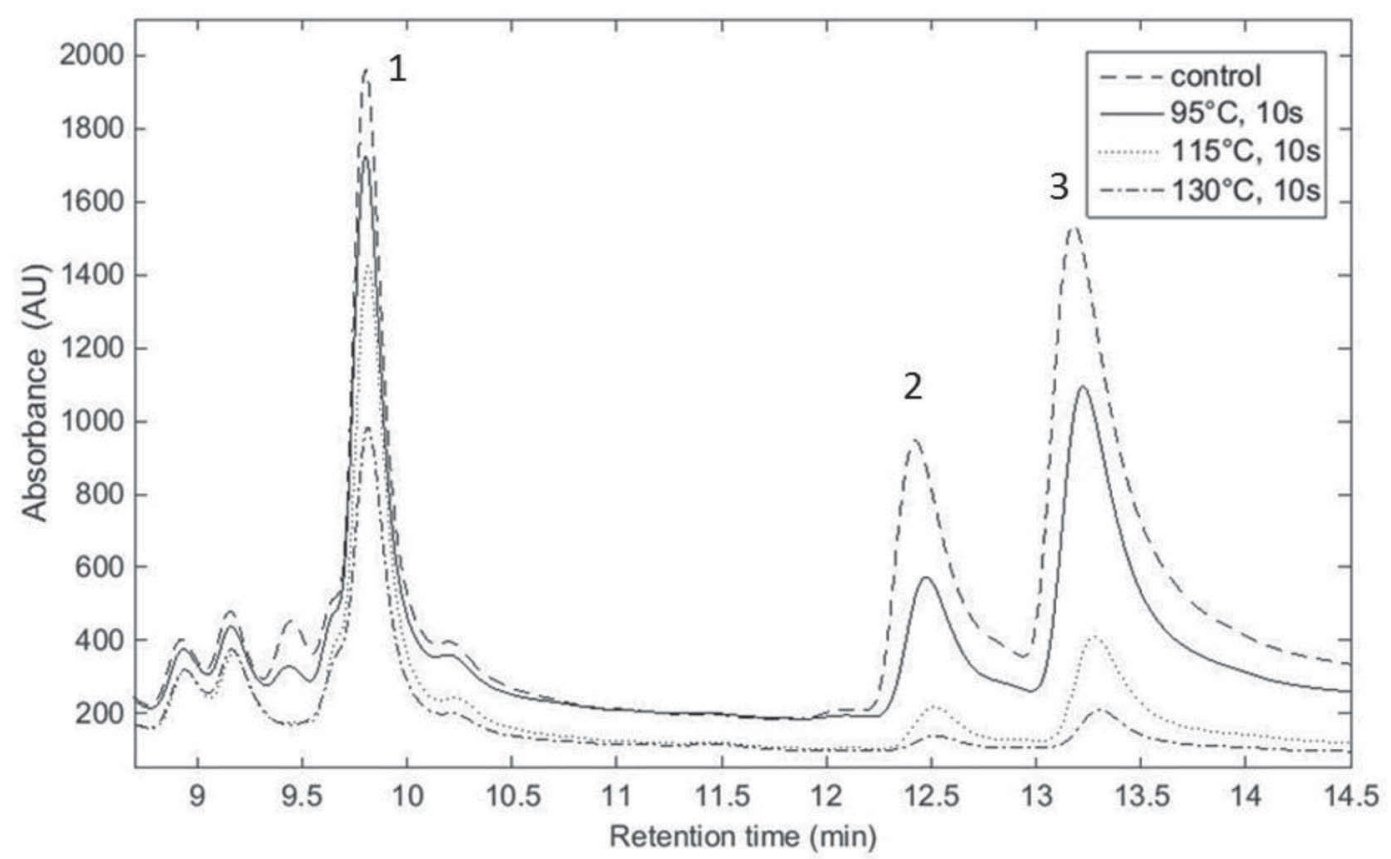

Figure 1. A UV chromatogram from the liquid chromatography quadrupole time-of-flight mass spectrometry analysis of $\mathrm{pH}$ 4.5-soluble protein from control skim milk (dashed line) and skim milk heated at $95^{\circ} \mathrm{C}$ (solid line), $115^{\circ} \mathrm{C}$ (dotted line), and $130^{\circ} \mathrm{C}$ (dashed-dotted line) heat treated using a plate heat exchanger. The detected proteins are $\alpha-\mathrm{LA}(1), \beta-\mathrm{LG} \mathrm{B}(2)$, and $\beta$-LG A (3). The UV absorbance at 214 nm is shown in absorption units (AU). Peak areas were used to calculate denaturation degrees as the difference in peak area of a heat-treated sample compared with a control sample.

is clear at $T>85^{\circ} \mathrm{C}$, as seen in Figure $2 \mathrm{~A}$ and Figure $2 \mathrm{C}$. Temperatures $\geq 115^{\circ} \mathrm{C}$ result in denaturation degrees $>90 \%$ for $\beta$-LG $\mathrm{B}$, at all measured holding times, as shown in Figure 2B. Compared with $\beta$-LG A, $\beta-L G$ B was found to have a slightly higher degree of denaturation, but this was not statistically significant (data not shown). This is consistent with earlier reports in the literature, where $\beta$-LG A has a slightly lower denaturation temperature, but because of a higher negative charge, the unfolded protein tends to form less aggregates compared with $\beta$-LG B (Schokker et al., 2000; O'Connell and Fox, 2011). $\alpha$-Lactalbumin had the least denaturation at all measured $T$ and holdingtime combinations and heating methods, as shown in Figure 2C and Figure 2D. $\alpha$-Lactalbumin has a tendency to refold into native structure at temperatures below $80^{\circ} \mathrm{C}$, whereas higher temperatures are required to form aggregates with other proteins, which may explain the lower degree of denaturation observed for $\alpha$-LA compared with that of $\beta$-LG (Eigel et al., 1984; Calvo et al., 1993; Wang et al., 2006). Comparing the 2 indirect heating methods, PHE and THE, heating with THE resulted in significantly higher denaturation degrees of all whey proteins measured compared with heat treatment by PHE $(P<0.001)$. At $\geq 95^{\circ} \mathrm{C}$, more than $90 \%$ of $\beta$-LG B was denatured for heat treatments using either method, PHE or THE.
From Figure 2, it is evident that the denaturation degrees obtained in the present study for heating at $T<90^{\circ} \mathrm{C}$ by THE show similar tendencies as shown by Dannenberg and Kessler (1988), who used a laboratory-scale tubular heating system. Dannenberg and Kessler (1988) observed denaturation degrees of $\beta$-LG B below $50 \%$ for all holding times studied, which is in agreement with the present study. However, heating at $T>90^{\circ} \mathrm{C}$, the denaturation degrees of $\beta$-LG B reported here are substantially larger compared with Dannenberg and Kessler (1988). Heating at a temperature of $140^{\circ} \mathrm{C}$ for $5 \mathrm{~s}$ using PHE resulted in a denaturation degree of $94 \%$ for $\beta$-LG B in the present study, whereas Dannenberg and Kessler (1988) reported denaturation degrees slightly above $60 \%$. These variations were also found when comparing heating using THE in the present study and results by Dannenberg and Kessler (1988). The same tendency can be seen by comparing denaturation degrees of $\beta-\mathrm{LG} A$ and $\alpha$-LA with the results of Dannenberg and Kessler (1988). Major differences between the present study and the study by Dannenberg and Kessler (1988) are (1) the analysis method for detecting the denaturation degree and (2) scaling of the heating systems used.

It can be stated that isoelectric focusing on polyacrylamide gel, as applied by Dannenberg and Kessler (1988), provides a more limited separation and quan- 
tification than liquid chromatography-mass spectrometry, which limits precise quantification at low and high denaturation degrees (McDonald et al., 2002; Mann and Jensen, 2003; Dauly et al., 2006; Rabilloud et al., 2010; Abdallah et al., 2012), because of poorer dynamic range of gel-based techniques compared with liquid chromatography-based techniques (Wedholm et al., 2008; Larsen et al., 2010; Jensen et al., 2012).
Furthermore, the use of a pilot-scale heating system with a preheating section extends the time before reaching the desired temperature, which gives a prolonged total heating profile. This will give rise to higher denaturation degrees compared with a small laboratoryscale heating system with short preheating and cooling time (Deeth and Datta, 2002). Heat treatment of milk made on small laboratory heating systems could also be
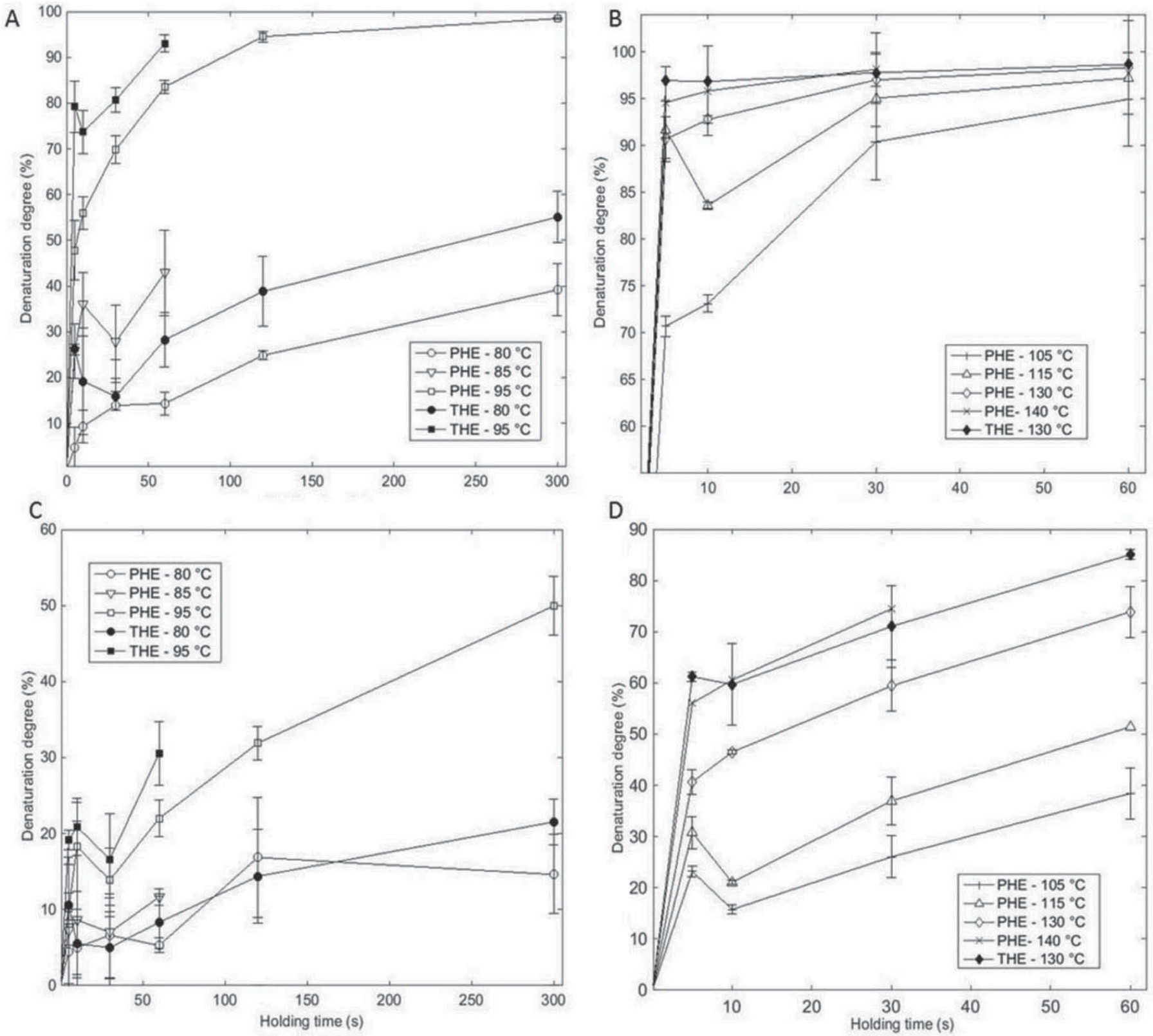

Figure 2. Denaturation degrees of $\beta$-LG B and $\alpha$-LA for skim milk heated using a plate heat exchanger (PHE) or tubular heat exchanger (THE) at temperatures from 80 to $140^{\circ} \mathrm{C}$ with holding times from 5 to $300 \mathrm{~s}$. The data were obtained from integration areas from the chromatograms, as shown in Figure 1. (A) Denaturation of $\beta$-LG B heated at temperatures below $100^{\circ} \mathrm{C}$. (B) Denaturation of $\beta$-LG B heated at temperatures above $100^{\circ} \mathrm{C}$. (C) Denaturation of $\alpha$-LA heated at temperatures below $100^{\circ} \mathrm{C}$. (D) Denaturation of $\alpha$-LA heated at temperatures above $100^{\circ} \mathrm{C}$. The results are shown as least squares means of duplicate analyses for each of 2 replicate trials $(\mathrm{n}=4) \pm$ standard deviation. 
difficult to reproduce in large-scale production, because the heating process will often have different flow rates, heat transfer rates, and turbulence. It could be argued that the heat transfer and heat distribution is better in the present study compared with using laboratory-scale heating, because of large milk flow and corrugations of the plates and tubes.

\section{Whey Protein Denaturation Kinetics}

Denaturation kinetics of the whey proteins was determined for heat treatment using PHE and THE. The order of reaction of 1.5 was used for $\beta-\mathrm{LG}$ and 1 for $\alpha-\mathrm{LA}$ according to previous studies (Dannenberg and Kessler, 1988; Kessler and Beyer, 1991; Oldfield et al., 1998b; Zúñiga et al., 2010). Equation [1] was used to linearize the denaturation of $\beta-\mathrm{LG} B$ and $\alpha-\mathrm{LA}$, heated using PHE, as an effect of holding time for each temperature. This is shown in Figure 3 along with fitted regression lines. $\beta$-Lactoglobulin A follows a similar pattern as $\beta-L G$ B and is therefore not shown graphically. High correlation coefficients for linear regressions were found for all temperatures analyzed. The calculated rate constants, $k$, obtained from Figure 3, are shown in Table 2 along with calculated rate constants for $\beta$-LG A heated using PHE and whey protein denaturation heated using THE. No further kinetics parameters could be calculated for heat treatment using THE, as only 3 temperatures were employed for this heat treatment. The rate constant, $k$, increases as the temperature increases for all whey proteins (Table 2). The largest increase in $k$ was found for $T>100^{\circ} \mathrm{C}$. The rate constants achieved by heating using THE are larger than rate constants obtained by heating using PHE, but not significantly different $(P>0.14)$, when comparing the whole temperature range from 80 to $140^{\circ} \mathrm{C}$ for the 2 methods. This was also seen when comparing the denaturation degrees in Figure 2. Differences in whey protein denaturation can be caused by differences in the heating method. The heat transfer is expected to be more efficient in PHE because of larger surface area for heat transfer and corrugation of the plates, which induces a more turbulent milk flow to the system. The shape of the tubes results in a more unequal heat distribution and lower heat transfer and turbulence compared with heat treatment using PHE. These observations in variations between heating methods are consistent with previous literature (Deeth and Datta, 2002). This could indicate that the high heat transfer and slightly shorter total heating time for PHE leads to lower denaturation degree compared with THE.

The rate constants obtained for the heating using PHE were used to analyze the effect of temperature on the rate constant. From the Arrhenius equation it is possible to calculate the activation energy. Figure 4 shows the effect of temperature on the rate constants for $\beta$-LG B, $\beta$-LG A, and $\alpha-\mathrm{LA}$ for heat treatment by PHE. The obtained kinetic data from Figure 4 are given in Table 3 . The reaction kinetics were found to be linear in 2 temperature ranges for all whey proteins. Large activation energy was found for $T<95^{\circ} \mathrm{C}$ and low activation energies for $T>95^{\circ} \mathrm{C}$. This is consistent with previous studies, indicating that the unfolding reaction of the proteins requires more energy than the aggregation reaction (Dannenberg and Kessler, 1988; Kessler and Beyer, 1991; Oldfield et al., 1998b; Zúñiga et al., 2010). The denaturation degree and reaction kinetics observed in the present study differ from previous findings. The activation energy found in the present study was lower at $T<95^{\circ} \mathrm{C}$ and higher for $T>95^{\circ} \mathrm{C}$ compared with previous studies (Singh and Latham, 1993; Corredig and Dalgleish, 1996; Donato et al., 2007). This implies that less energy is required to unfold the whey proteins in the present study. These changes could be raised from differences in the heating system, total heating time, and analytical methods used for determination of the denaturation degree.

\section{Rennet-Induced Coagulation of Indirectly Heated Skim Milk}

Rennet-induced coagulation properties for heattreated skim milk samples were analyzed by use of a ReoRox rheometer. The relative change in RCT and relative change in CFR compared with the control samples are shown to characterize the coagulation process of differentially heat-treated skim milk. Both of these parameters lie within the second phase of the rennet coagulation process, which describes the aggregation phase the rennet-modified casein micelles. Figure 5 shows the relative RCT and relative CFR for heat-treated skim milk samples as heated by PHE and THE. The rennet-induced coagulation properties were impaired with increasing holding time for all temperatures $(P<0.001)$.

The relative RCT was only slightly increasing when heating at $T \leq 85^{\circ} \mathrm{C}$, whereas $T \geq 85^{\circ} \mathrm{C}$ resulted in significant increase in relative RCT $(P<0.001)$, which is shown in Figure 5A. This is consistent for both heating methods, and no significant differences were found between the heating methods $(P>0.43)$. Even though the RCT did not increase significantly at these temperatures, a large effect on the CFR was observed, as shown in Figure 5C. Heat treatment using THE resulted in significant larger decrease in relative CFR compared with PHE $(P<0.001)$. Heating at $T>95^{\circ} \mathrm{C}$, 
A
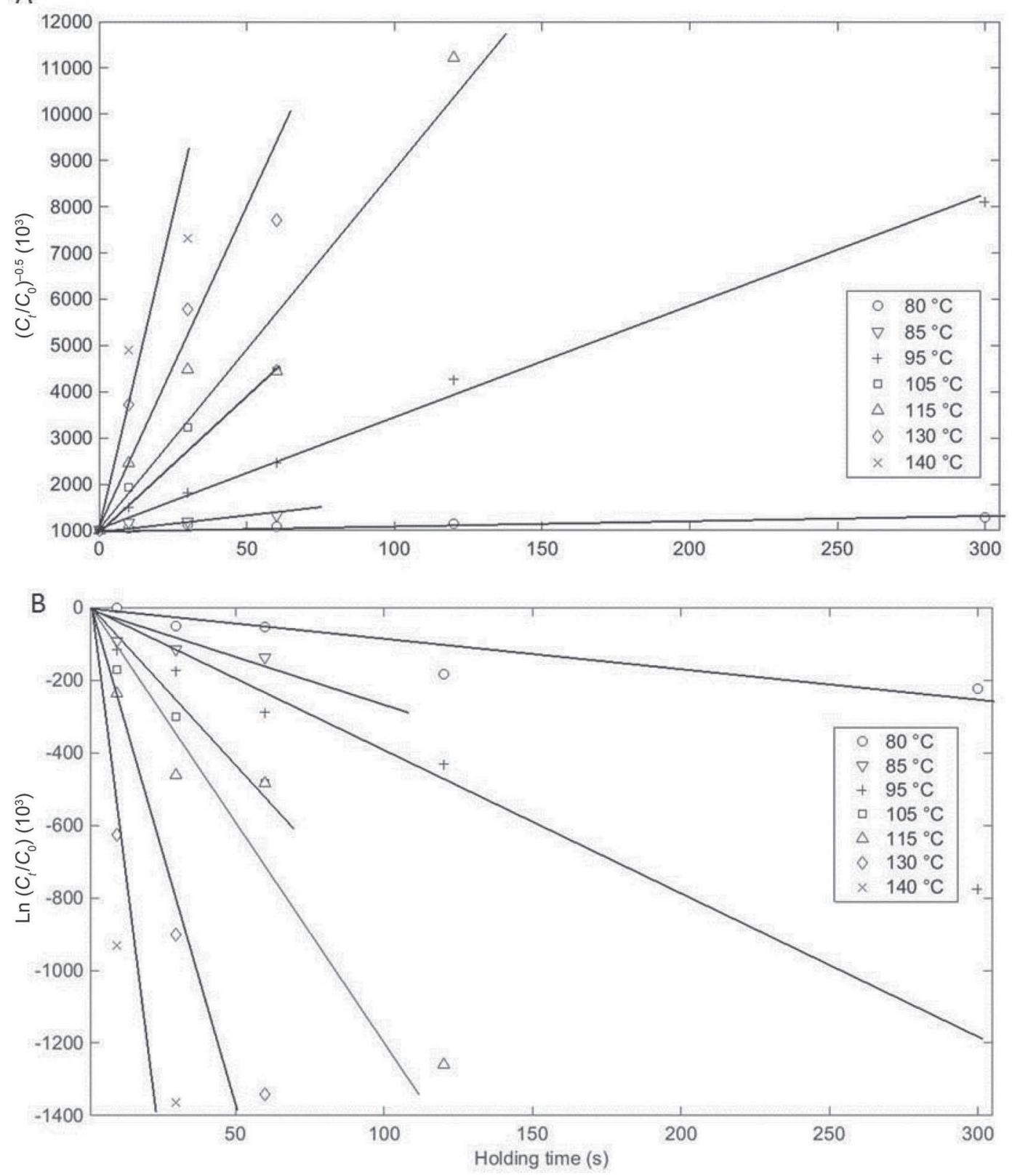

Figure 3. Least squares means of the denaturation degree of $\beta$-LG B and $\alpha$-LA for skim milk samples heated with a plate heat exchanger at temperatures from 80 to $140^{\circ} \mathrm{C}$ at various holding times. For each temperature, a linear regression was fitted, which is shown in Table 2 . The general rate equation [1] was used, with reaction orders $(n)$ defined according to previous studies and $C_{0}$ and $C_{t}$ being the denaturation degrees at control and a specific heating condition, respectively. (A) Denaturation of $\beta$-LG with $n=1.5$. (B) Denaturation of $\alpha$-LA with $n=1$. Equal calculations were made for $\beta$-LG A and for heat treatment using a tubular heat exchanger and are shown in Table 2 .

shown in Figure 5B and Figure 5D, resulted in large impairments of relative RCT and relative $\mathrm{CFR}(P<$ 0.001). For heat treatments at $130^{\circ} \mathrm{C}$ using PHE, very low or no value of CFR was detected at any holding time, whereas CFR was detected for all samples heated using THE.
Comparing the relative RCT and denaturation degree of $\beta$-LG B, it was found that a denaturation degree $<60 \%$ did not affect the rennet coagulation time, whereas curd firming rates were much more sensitive to denaturation. This is consistent with previous studies (Waungana et al., 1996; Anema et al., 2011; Blecker 


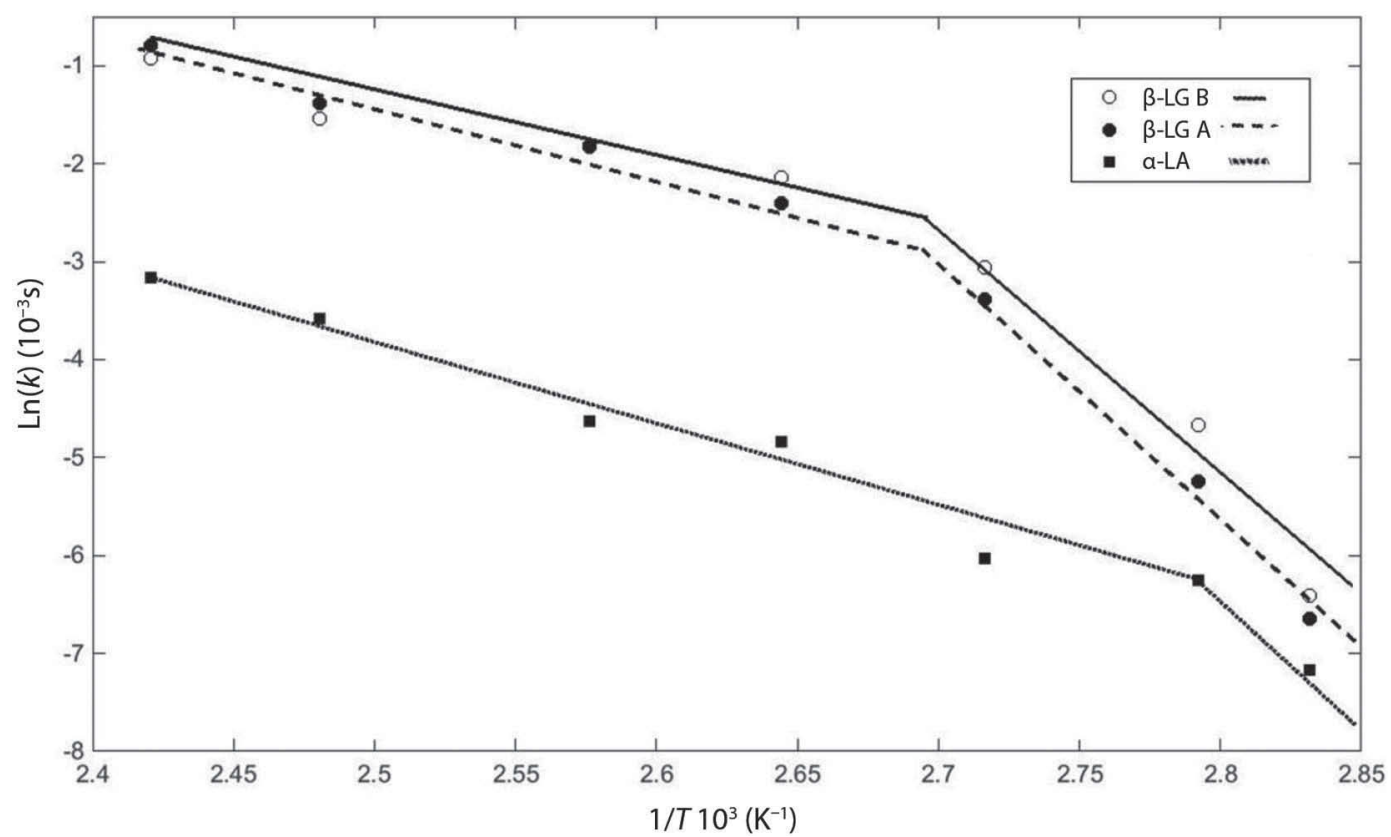

Figure 4. Arrhenius plots illustrating the effect of temperature $(T)$ on rate constant $(k)$ for denaturation of $\beta$-LG B, $\beta$-LG A, and $\alpha$-LA for skim milk heated by a plate heat exchanger. Linear regressions are fitted in the inverse temperature range from 2.42 to 2.70 and 2.70 to 2.85 for $\beta$-LG B and $\beta$-LG A and from 2.42 to 2.80 and 2.80 to 2.85 for $\alpha$-LA.

et al., 2012). Denaturation degrees $>70 \%$ resulted in lower increase in relative RCT for heat treatments by THE compared with PHE with the same denaturation degree. It is likely not only the degree of whey protein denaturation that is important for the rennet coagulation properties, but also how these denatured proteins

Table 2. Rate constant $(k)$ and correlation coefficient $\left(\mathrm{R}^{2}\right)$ of reaction kinetics on denaturation of $\beta$-LG B, $\beta$-LG A, and $\alpha$-LA in skim milk heated by plate heat exchanger (PHE) and tubular heat exchanger (THE) ${ }^{1}$

\begin{tabular}{|c|c|c|c|c|c|}
\hline \multirow[b]{2}{*}{ Item } & \multirow[b]{2}{*}{$\begin{array}{l}\text { Temperature } \\
\left({ }^{\circ} \mathrm{C}\right)\end{array}$} & \multicolumn{2}{|c|}{ PHE } & \multicolumn{2}{|c|}{ THE } \\
\hline & & $\begin{array}{l}\text { Rate constant } \\
\qquad\left(k ; 10^{3} / \mathrm{s}\right)\end{array}$ & $\mathrm{R}^{2}$ & $\begin{array}{l}\text { Rate constant } \\
\quad\left(k ; 10^{3} / \mathrm{s}\right)\end{array}$ & $\mathrm{R}^{2}$ \\
\hline \multirow[t]{7}{*}{$\beta-\mathrm{LG} B$} & 80 & $1.28 \pm 0.12$ & 0.91 & $3.05 \pm 0.29$ & 0.85 \\
\hline & 85 & $10.51 \pm 1.39$ & 0.91 & & \\
\hline & 95 & $45.35 \pm 1.40$ & 0.98 & $85.21 \pm 5.26$ & 0.95 \\
\hline & 105 & $98.57 \pm 4.75$ & 0.97 & & \\
\hline & 115 & $160.28 \pm 6.31$ & 0.97 & & \\
\hline & 130 & $217.04 \pm 25.89$ & 0.82 & $290.32 \pm 37.78$ & 0.86 \\
\hline & 140 & $449.25 \pm 42.83$ & 0.85 & & \\
\hline \multirow[t]{7}{*}{$\beta$-LG A } & 80 & $1.29 \pm 0.13$ & 0.92 & $2.20 \pm 0.15$ & 0.89 \\
\hline & 85 & $5.66 \pm 0.49$ & 0.94 & & \\
\hline & 95 & $34.33 \pm 1.16$ & 0.98 & $49.09 \pm 4.37$ & 0.89 \\
\hline & 105 & $91.12 \pm 6.73$ & 0.96 & & \\
\hline & 115 & $167.84 \pm 7.16$ & 0.96 & & \\
\hline & 130 & $255.23 \pm 21.30$ & 0.88 & $398.52 \pm 39.20$ & 0.91 \\
\hline & 140 & $509.01 \pm 34.29$ & 0.85 & & \\
\hline \multirow[t]{6}{*}{$\alpha-\mathrm{LA}$} & 80 & $0.68 \pm 0.05$ & 0.95 & $0.88 \pm 0.08$ & 0.85 \\
\hline & 85 & $2.08 \pm 0.32$ & 0.83 & & \\
\hline & 95 & $2.07 \pm 0.15$ & 0.91 & $6.50 \pm 0.79$ & 0.87 \\
\hline & 105 & $8.52 \pm 1.03$ & 0.86 & & \\
\hline & 115 & $9.57 \pm 0.40$ & 0.97 & & \\
\hline & 130 & $21.60 \pm 2.33$ & 0.83 & $24.77 \pm 2.63$ & 0.90 \\
\hline
\end{tabular}

${ }^{1}$ Results are obtained from kinetic plots, as shown in Figure 3, and the corresponding linear regressions of these. The results are shown as LSM of duplicate analyses for each of 2 replicate trials $(\mathrm{n}=4) \pm \mathrm{SD}$. 
interact with other proteins (Poulsen et al., 2015). It can be speculated that heat treatment of skim milk by THE gives larger structural changes in the casein micelles compared with THE. It is well known that heat treatment of skim milk leads to formation of aggregates containing denatured whey proteins as well as forming disulfide-bonded interactions between $\kappa-\mathrm{CN}$ and denatured whey proteins, and especially $\beta$-LG (GravelandBikker and Anema, 2003; Tran Le et al., 2008). The formation of large heat-induced aggregates of whey proteins using THE, which are not attached to caseins upon the casein micelle, could be more pronounced by heat treatment using THE. Dalgleish (1990) observed an increase in size of heat-induced aggregates as the denaturation of whey proteins increased. The formations of these complexes are altered by prolonged heating time with a slow heating process, as PHE and THE compared with DSI. Formation of the heat-induced aggregates would therefore be expected to be more pronounced in heat treatments using THE compared with PHE because the heating profile is larger for THE than for PHE. These large complexes are thereby thought to give rise to less steric hindrance for the rennet cleavage, whereas smaller complexes might have a higher affinity for binding to the casein micelles, and thereby produce more steric hindrance for rennet cleavage (Anema et al., 2007).

Formation of lactose and casein complexes due to heat treatment has been demonstrated to occur in milk (Turner et al., 1978; van Boekel, 1998). These complexes could be speculated to induce steric hindrance for rennet cleavage of $\kappa-\mathrm{CN}$ and thereby contribute to the decrease in rennet-induced coagulation abilities. It has furthermore been stated that degradation of lactose is responsible for formations of formic acid, which can result in small decreases in the $\mathrm{pH}$ of milk and thereby induce solubilization of some of the micellar calcium phosphate (Turner et al., 1978; Martinez-Castro et al., 1986). No clear trend in change of $\mathrm{pH}$ was found for heat-treated samples in the present study (data not shown).

\section{Effect of Heating by Direct Steam Injection}

Heat treatment by DSI was performed at $4 T$ : 105, 115,130 , and $145^{\circ} \mathrm{C}$ with a holding time of $4 \mathrm{~s}$, because this was the limit of the employed DSI heating system. Whey protein denaturation degrees and rennet-induced coagulation properties are shown in Table 4. An increase in whey protein denaturation and impairment of the rennet-induced coagulation properties were observed with increasing $T$. The DSI heating system was found to be very different from the 2 indirect heating methods. Direct steam injection resulted in significant lower denaturation degrees of $\beta$-LG and $\alpha$-LA $(P<$ 0.001) compared with the 2 indirect heating systems studied, THE and PHE (Figure 5), when comparing at equal $T$ with $1 \mathrm{~s}$ in variation in holding time. This is consistent with results obtained by Hammersh $\varnothing$ j et al. (2010) and Dickow et al. (2012), who compared whey protein denaturation by use of lenient steam injection and instant infusion pasteurization, respectively, with indirect heating by use of PHE.

The rennet coagulation properties were also less affected by the direct heat treatment compared with indirect heating. The heating profile of DSI is different from the 2 indirect methods by having a very short heating time from preheat temperature to the desired $T$ and a flash cooling to $65^{\circ} \mathrm{C}$ before reaching the 3 plate cooling sections. No or very low whey protein denaturation was observed upon heating skim milk at $105^{\circ} \mathrm{C}$ by DSI (Table 4). As the preheating and cooling sections were performed by PHE, it could be expected to induce some whey protein denaturation. Hougaard et al. (2009), Dickow et al. (2012), and Rauh (2014) observed high degree of $\beta$-LG denaturation by use of DSI infusion heat treatment of semi-skim milk, which could be related to the preheating time and $T$.

The preheating temperature used here was slightly higher than the pasteurization temperature, which has generally been reported to lead to a whey protein denaturation degree of less than 5\% (Fox et al., 2000; Dickow, 2011). The fast heating and flash cooling times give less

Table 3. Reaction kinetic parameters rate constant at 1 /temperature $=0\left(k_{0}\right)$, activation energy $\left(E_{\mathrm{a}}\right)$, and correlation coefficient $\left(\mathrm{R}^{2}\right)$ for denaturation of $\beta$-LG B, $\beta$-LG A, and $\alpha$-LA for skim milk heated by $\mathrm{PHE}^{1}$

\begin{tabular}{lccccc}
\hline Item & $\begin{array}{c}\text { Reaction } \\
\text { order }(n)\end{array}$ & $\begin{array}{c}\text { Temperature } \\
\text { range }\left({ }^{\circ} \mathrm{C}\right)\end{array}$ & $\ln \left(k_{0}\right)$ & $\begin{array}{c}\text { Activation } \\
\text { energy }\left(E_{\mathrm{a}}\right)\end{array}$ & $\mathrm{R}^{2}$ \\
\hline$\beta$-LG B & 1.5 & $80-95$ & $74.08 \pm 3.06$ & $250.78 \pm 9.71$ & 0.99 \\
$\beta$-LG A & 1.5 & $95-140$ & $11.17 \pm 1.38$ & $61.77 \pm 3.99$ & 0.95 \\
& & $80-95$ & $72.54 \pm 3.76$ & $246.58 \pm 11.92$ & 0.98 \\
$\alpha$-LA & 1 & $95-140$ & $19.54 \pm 1.18$ & $73.84 \pm 4.08$ & 0.96 \\
& & $80-85$ & $72.30 \pm 7.30$ & $248.23 \pm 23.03$ & 0.97 \\
\hline
\end{tabular}

${ }^{1}$ The values are calculated from data obtained from Figure 4 by use of the Arrhenius equation [2]. The results are shown as LSM of duplicate analyses for each of 2 replicate trials $(\mathrm{n}=4) \pm \mathrm{SD}$. 
A
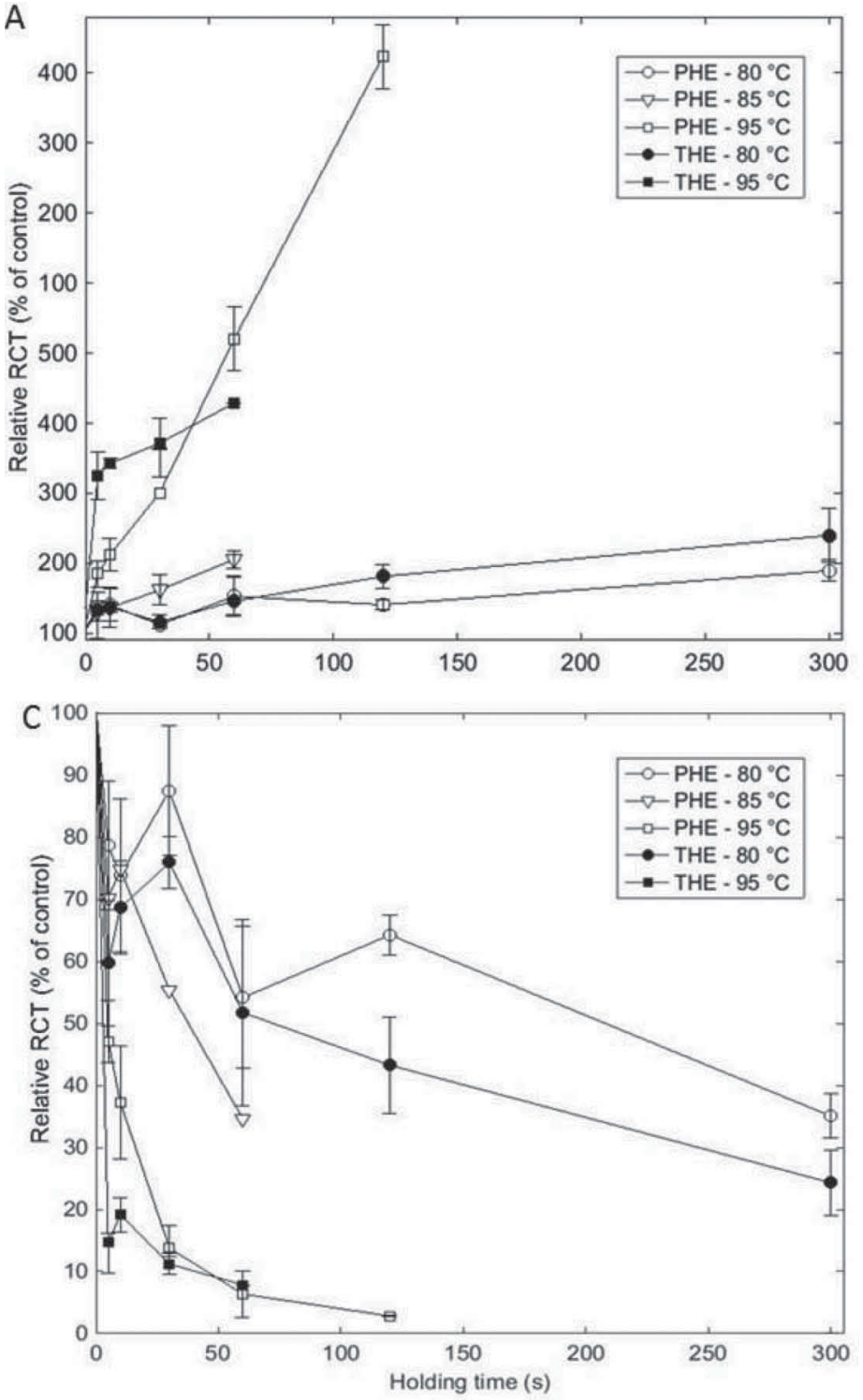
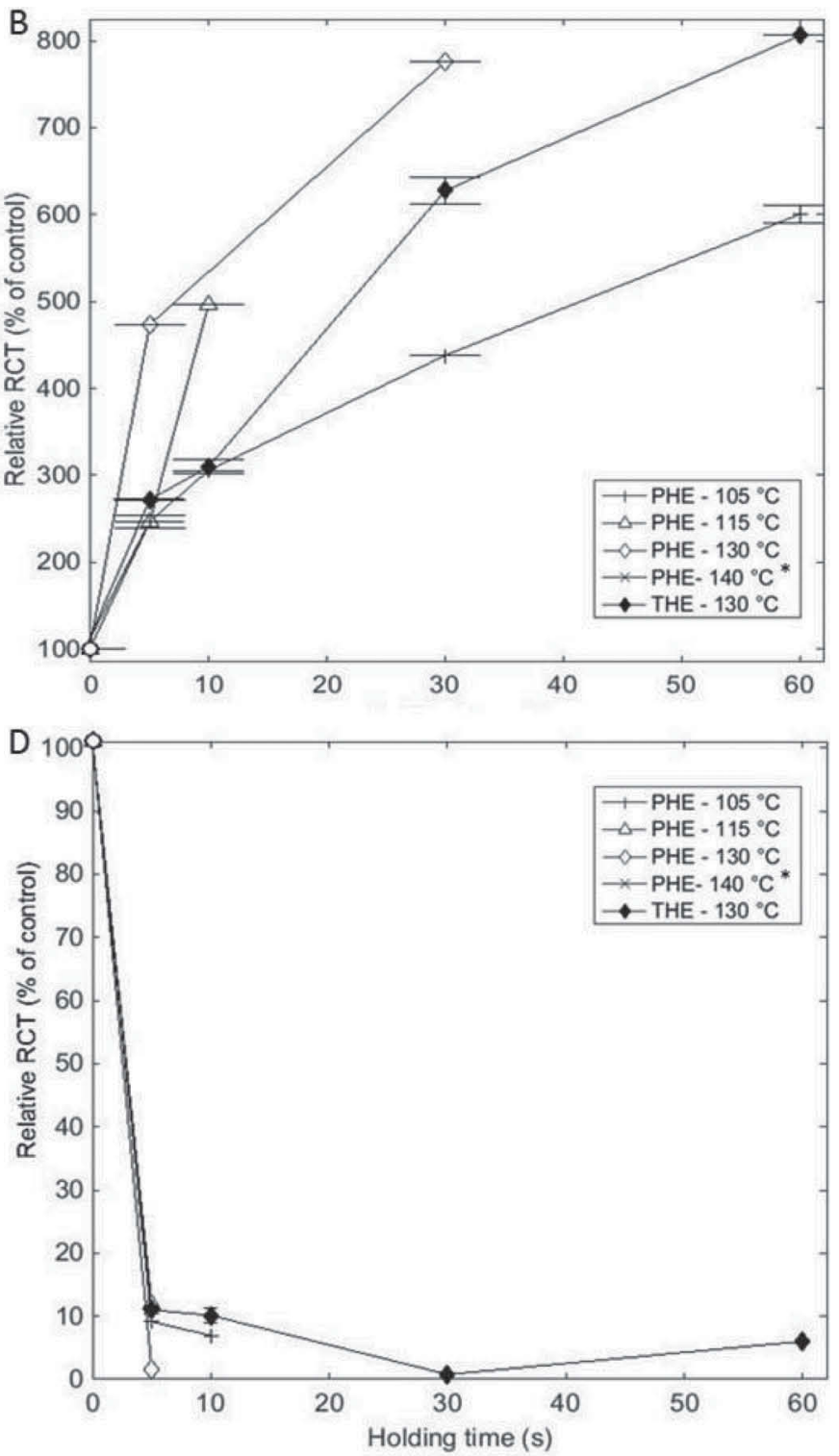

Figure 5. The relative rennet coagulation time (RCT) and curd firming rate (CFR) for skim milk samples heated by a plate heat exchanger (PHE) or tubular heat exchanger (THE) at temperatures from 80 to $140^{\circ} \mathrm{C}$ with holding times from 5 to $60 \mathrm{~s}$. (A) Relative RCT of skim milk heated by PHE or THE at temperatures below $100^{\circ} \mathrm{C}$. (B) Relative RCT of skim milk heated by PHE or THE at temperatures above $100^{\circ} \mathrm{C}$. *No RCT was detected for prolonged holding times. (C) Relative CFR for skim milk heated by PHE or THE at temperatures below $100^{\circ} \mathrm{C}$. (D) Relative CFR for skim milk heated by PHE or THE at temperatures above $100^{\circ} \mathrm{C}$. ${ }^{*}$ No $\mathrm{CFR}$ was detected for prolonged holding times. The results are shown as least squares means of duplicate analyses for each of 2 replicate trials $(\mathrm{n}=4) \pm$ standard deviation.

time for formation of aggregates, and denatured whey proteins could therefore be permitted to refold into native structures. Refolding into nonnative structures would probably result in a change in retention time in the LC/MS Q-ToF analysis, and furthermore, it can be speculated that refolding could lead to aggregation of proteins, which would potentially precipitate at $\mathrm{pH} 4.5$ as used in the present study for separation of unfolded whey proteins from native structures (Ahuja, 2000; Carr, 2002).
The injection of steam into the preheated milk gives a good heat transfer because of mixing of milk and steam, but this also induces more instant heat to the milk. This can be seen when heating at $T$ of $130^{\circ} \mathrm{C}$, where DSI had a low denaturation degree compared with skim milk samples heated by PHE and THE, but this gave rise to a 3 -times-higher relative $\mathrm{RCT}$ compared with samples heated indirectly with same denaturation degree. The increase in relative RCT can thereby not be explained only by the denaturation of 
Table 4. Relative rennet coagulation time (RCT), relative curd firming rate (CFR), and denaturation degrees of whey proteins for heating skim milk using direct steam injection for each temperature ${ }^{1}$

\begin{tabular}{lccccr}
\hline $\begin{array}{l}\text { Temperature/ } \\
\text { holding time } \\
\left({ }^{\circ} \mathrm{C} / \mathrm{s}\right)\end{array}$ & $\begin{array}{c}\text { Relative } \\
\text { RCT }(\%)\end{array}$ & $\begin{array}{c}\text { Relative } \\
\text { CFR }(\%)\end{array}$ & $\begin{array}{c}\text { Denaturation } \\
\beta \text {-LG B (\%) }\end{array}$ & $\begin{array}{c}\text { Denaturation } \\
\beta \text {-LG A (\%) }\end{array}$ & $\begin{array}{c}\text { Denaturation } \\
\alpha \text {-LA (\%) }\end{array}$ \\
\hline $105 / 4$ & $127.46 \pm 13.91$ & $56.52 \pm 2.19$ & $0.79 \pm 4.29$ & $11.66 \pm 3.21$ & $4.80 \pm 1.21$ \\
$115 / 4$ & $138.92 \pm 10.56$ & $45.46 \pm 5.20$ & $15.75 \pm 11.63$ & $24.64 \pm 9.28$ & $9.23 \pm 1.92$ \\
$130 / 4$ & $192.26 \pm 40.79$ & $24.86 \pm 8.67$ & $25.29 \pm 4.86$ & $30.91 \pm 2.66$ & $10.53 \pm 5.65$ \\
$145 / 4$ & $420.81^{2}$ & $-{ }^{3}$ & $39.35 \pm 2.83$ & $46.83 \pm 4.44$ & $15.35 \pm 2.97$ \\
\hline
\end{tabular}

${ }^{1}$ The results are shown as LSM of duplicate analyses for each of 2 replicate trials $(n=4) \pm$ SD.

${ }^{2}$ Only one measurement reached RCT.

${ }^{3}$ No CFR was detected for all measurements.

whey proteins, but the temperature also has a great effect. Furthermore, these high $T$ can induce other changes in milk, such as mineral precipitation, lactose degradations, and heat-induced protein aggregations

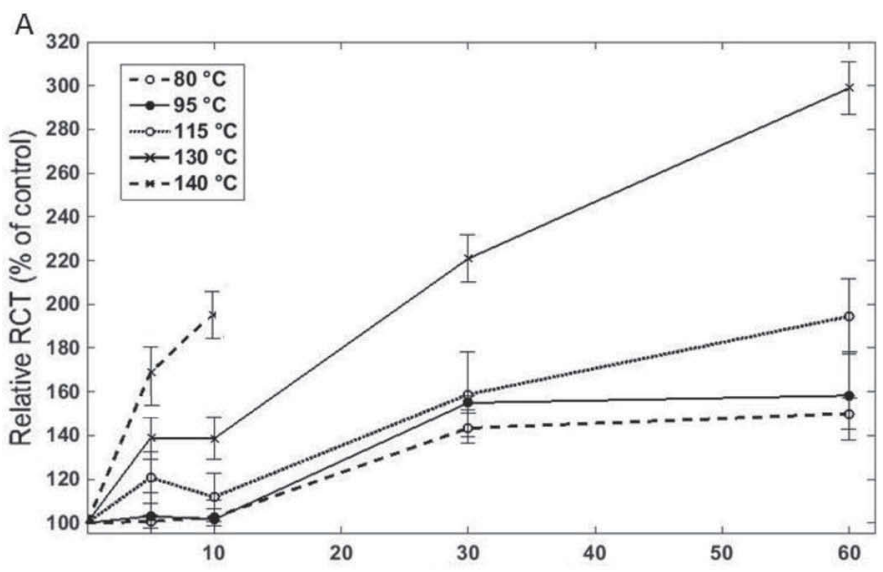

B

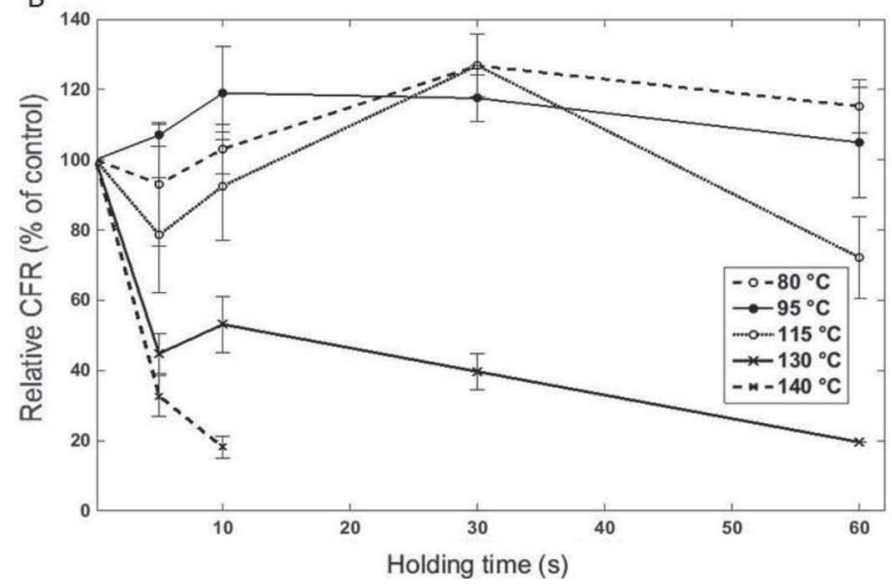

Figure 6. Relative rennet coagulation time (RCT; A) and relative curd firming rate (CFR; B) for micellar casein concentrate milk heated using a plate heat exchanger at temperatures from 80 to $140^{\circ} \mathrm{C}$ with holding times from 5 to $60 \mathrm{~s}$. The results are shown as least squares means of duplicate analyses for each of 2 replicate trials \pm standard deviation.
(Oldfield et al., 1998a; Walstra et al., 1999; Lewis and Deeth, 2008).

\section{Effect of Removal of Whey Proteins from Skim Milk}

The effect of removal of whey proteins from skim milk was studied by comparing with behavior of MCC. Initially, it was observed that control samples of MCC had a significantly lower RCT and higher CFR compared with control samples of skim milk of comparable total protein content (data not shown). This can be ascribed to variations in casein content between skim milk and MCC (Casiraghi et al., 1989; Frederiksen et al., 2011). An increase in the casein content and removal of whey protein are known to cause a decrease in RCT and CFR (Pierre et al., 1992; Guinee et al., 1996; Wedholm et al., 2006; Wang et al., 2007; Jõudu et al., 2008).

The relative RCT and CFR for MCC milk heated by PHE are shown in Figure 6. An increase in relative RCT was found for all heat-treated MCC samples. These increases were significantly lower compared with heat-treated skim milk $(P<0.001)$, and RCT was detected for all heat treatments within the $2 \mathrm{~h}$ of measurement, which was not the case for heat-treated skim milk (Figure 5). The relative CFR increased for heating at $T<100^{\circ} \mathrm{C}$ but decreased when heating at $T>100^{\circ} \mathrm{C}$. The change in rennet-induced coagulation properties by heating at $T>100^{\circ} \mathrm{C}$ indicates that heat treatment results in changes in the casein micelle, even though both caseins and casein micelles have generally been stated to be relatively heat stable (Horne, 2008). O'Connell and Fox (2003) and Sauer and Moraru (2012) observed an increase in the amount of soluble casein and $\kappa-\mathrm{CN}$ could be removed from the micellar surface at normal $\mathrm{pH}$ of milk by heat treatment at $T$ $>100^{\circ} \mathrm{C}$. Furthermore, as expected, a decrease in the amount of soluble phosphate and calcium was observed when the $T$ was increased. Formation of crosslinks between caseins as well as dissociation of caseins from the micelle have been found when heating MCC solutions at high $T$ (Bulca and Kulozik, 2004). Mohammad and 
Fox (1987) also reported precipitation of calcium phosphate on the surface layer of casein micelles heating at high $T$, which hinders the rennet coagulation when heating at $140^{\circ} \mathrm{C}$. Further investigations on the formation of heat-induced aggregates of these heat-treated milk samples could help to explain the change in rennet coagulation properties of heat-treated milk.

\section{CONCLUSIONS}

The denaturation degree of whey proteins was found to be dependent on the heating system. The denaturation degree of whey proteins in skim milk increased when increasing holding time and increasing $T$ for all heating methods used. Heating using THE gave rise to significantly higher degrees of denaturation at $T$ $<100^{\circ} \mathrm{C}$, compared with PHE. Heating of skim milk using DSI resulted in significantly lower denaturation degrees compared with indirect heating. The rennet coagulation properties of skim milk were impaired when increasing holding time for all $T$ measured for all heating methods. Furthermore, heating of skim milk using DSI gave significantly smaller deterioration of rennet coagulation abilities compared with the indirect heating methods. The MCC significantly improved the rennet coagulation properties compared with skim milk at all $T$ and holding times. Further research is needed to evaluate the differences in heat-induced protein aggregation to determine the causes of differences between PHE and THE. Research on change in lactose, mineral balance, and bacterial load could also be beneficial to make a full characterization of the effect of the heating systems on milk.

\section{ACKNOWLEDGMENTS}

This study was supported by Arla Foods Amba (Brabrand, Denmark) and Aarhus University, Denmark. K. Matzen is thanked for his technical assistance in the dairy pilot plants at Arla Foods Strategic Innovation Centre (Brabrand, Denmark). Furthermore, P. N. Andersen, B. Hansen, and V. Mortensen are thanked for assistance in the laboratories at Arla Foods Strategic Innovation Centre.

\section{REFERENCES}

Abdallah, C., E. Dumas-Gaudot, J. Renaut, and K. Sergeant. 2012 Gel-based and gel-free quantitative proteomics approaches at a glance. Int. J. Plant Genomics 2012:494572. http://dx.doi. org $/ 10.1155 / 2012 / 494572$.

Abu-Khader, M. M. 2012. Plate heat exchangers: Recent advances. Renew. Sustain. Energy Rev. 16:1883-1891. http://dx.doi. org/10.1016/j.rser.2012.01.009.

Ahuja, S., ed. 2000. Handbook of Bioseparations. Acad. Press, London, UK.
Andersen, P. N. 2013. ReoRox G2 and Rheometer Comparison. Oral presentation, Arla Foods, Brabrand, Dennark.

Anema, S. G., S. Kim Lee, and H. Klostermeyer. 2007. Effect of pH at heat treatment on the hydrolysis of $\kappa$-casein and the gelation of skim milk by chymosin. LWT-Food Sci. Technol. (Campinas.) 40:99-106. http://dx.doi.org/10.1016/j.lwt.2005.08.002.

Anema, S. G., S. K. Lee, and H. Klostermeyer. 2011. Rennet-induced aggregation of heated $\mathrm{pH}$-adjusted skim milk. J. Agric. Food Chem. 59:8413-8422. http://dx.doi.org/10.1021/jf201198s.

Anema, S. G., and A. B. McKenna. 1996. Reaction kinetics of thermal denaturation of whey proteins in heated reconstituted whole milk. J. Agric. Food Chem. 44:422-428. http://dx.doi.org/10.1021/ jf950217q.

Blecker, C., J.-M. Habib-Jiwan, and R. Karoui. 2012. Effect of heat treatment of rennet skim milk induced coagulation on the rheological properties and molecular structure determined by synchronous fluorescence spectroscopy and turbiscan. Food Chem. 135:18091817. http://dx.doi.org/10.1016/j.foodchem.2012.06.035.

Bulca, S., and U. Kulozik. 2004. Heat-induced changes in native casein micelles obtained by microfiltration. Bull. IDF 389:36-39.

Calvo, M. M., J. Leaver, and J. M. Banks. 1993. Influence of other whey proteins on the heat-induced aggregation of $\alpha$-lactalbumin. Int. Dairy J. 3:719-727. http://dx.doi.org/10.1016/09586946(93)90085-E.

Carbonaro, M., F. Bonomi, S. Iametti, M. Cappelloni, and E. Carnovale. 1998. Aggregation of proteins in whey from raw and heat-processed milk: Formation of soluble macroaggregates and nutritional consequences. LWT-Food Sci. Technol. (Campinas.) 31:522-529. http://dx.doi.org/10.1006/fstl.1998.0408.

Carr, D. 2002. The Handbook of the Analysis and Purification of Peptides and Proteins by Reversed-Phase HPLC. 3rd ed. Grace Vydac, Hesperia, CA.

Casiraghi, E., M. Lucisano, and C. Peri. 1989. Rennet coagulation of milk retentates. 2. The combined effect of heat treatments and protein concentration. J. Dairy Sci. 72:2457-2463. http://dx.doi. org/10.3168/jds.S0022-0302(89)79385-1.

Corredig, M., and D. G. Dalgleish. 1996. Effect of temperature and $\mathrm{pH}$ on the interactions of whey proteins with casein micelles in skim milk. Food Res. Int. 29:49-55. http://dx.doi.org/10.1016/09639969(95)00058-5.

Creamer, L. K., S. M. Loveday, and L. Sawyer. (2011) Milk proteins: $\beta$-Lactoglobulin. Pages 787-794 in Encyclopedia of Dairy Sciences. 2nd ed. J. W. Fuquay, ed. Acad. Press, San Diego, CA.

Dalgleish, D. G. 1990. Denaturation and aggregation of serum proteins and caseins in heated milk. J. Agric. Food Chem. 38:1995-1999. http://dx.doi.org/10.1021/jf00101a001.

Dannenberg, F., and H.-G. Kessler. 1988. Reaction kinetics of the denaturation of whey proteins in milk. J. Food Sci. 53:258-263.

Dauly, C., D. H. Perlman, C. E. Costello, and M. E. McComb. 2006 Protein separation and characterization by np-RP-HPLC followed by intact MALDI-TOF mass spectrometry and peptide mass mapping analyses. J. Proteome Res. 5:1688-1700. http://dx.doi. org/10.1021/pr060108z.

Deeth, H. C., and N. Datta. 2002. Ultra-high temperature treatment (UHT): Heating systems. Pages 2642-2652 in Encyclopedia of Dairy Sciences. H. Roginski, ed. Elsevier, Oxford, UK.

Dickow, J. A. 2011. Lenient steam injection heat treatment of milk and whey protein concentrate: Impact on enzymatic activities, protein denaturation and functional properties. PhD Thesis. Dept. Food Sci., Aarhus Univ., Aarhus, Denmark.

Dickow, J. A., N. Kaufmann, L. Wiking, and M. Hammershøj. 2012. Protein denaturation and functional properties of lenient steam injection heat treated whey protein concentrate. Innov. Food Sci. Emerg. Technol. 13:178-183. http://dx.doi.org/10.1016/j. ifset.2011.11.005

Dissanayake, M., L. Ramchandran, O. N. Donkor, and T. Vasiljevic. 2013. Denaturation of whey proteins as a function of heat, $\mathrm{pH}$ and protein concentration. Int. Dairy J. 31:93-99. http://dx.doi. org/10.1016/j.idairyj.2013.02.002.

Donato, L., F. Guyomarc'h, S. Amiot, and D. G. Dalgleish. 2007. Formation of whey protein/k-casein complexes in heated milk: 
Preferential reaction of whey protein with $\kappa$-casein in the casein micelles. Int. Dairy J. 17:1161-1167. http://dx.doi.org/10.1016/j. idairyj.2007.03.011.

Edmond, S. 2001. Continuous heat processing. Pages 29-48 in Thermal Technologies in Food Processing. P. Richardson, ed. Elsevier, Amsterdam, the Netherlands.

Eigel, W. N., J. E. Butler, C. A. Ernstrom, H. M. Farrell Jr., V. R. Harwalkar, R. Jenness, and R. McL. Whitney. 1984. Nomenclature of proteins of cow's milk: Fifth revision. J. Dairy Sci. 67:15991631. http://dx.doi.org/10.3168/jds.S0022-0302(84)81485-X.

Farrell, H. M., Jr., R. Jimenez-Flores, G. T. Bleck, E. M. Brown, J. E. Butler, L. K. Creamer, C. L. Hicks, C. M. Hollar, K. F. Ng-KwaiHang, and H. E. Swaisgood. 2004. Nomenclature of the proteins of cows' milk - Sixth revision. J. Dairy Sci. 87:1641-1674. http:// dx.doi.org/10.3168/jds.S0022-0302(04)73319-6.

Fox, P. F., T. P. Guinee, T. M. Cogan, and P. L. H. McSweeney. 2000. Fundamental of Cheese Science. Aspen Publ., Gaithersburg, MD.

Frederiksen, P. D., M. Hammershøj, M. Bakman, P. N. Andersen, J. B. Andersen, K. B. Quist, and L. B. Larsen. 2011. Variations in coagulation properties of cheese milk from three Danish dairy breeds as determined by a new free oscillation rheometry-based method. Dairy Sci. Technol. 91:309-321.

Graveland-Bikker, J. F., and S. G. Anema. 2003. Effect of individual whey proteins on the rheological properties of acid gels prepared from heated skim milk. Int. Dairy J. 13:401-408. http://dx.doi. org/10.1016/S0958-6946(02)00190-5.

Guinee, T. P., D. J. O'Callaghan, P. D. Pudja, and N. O'Brien. 1996. Rennet coagulation properties of retentates obtained by ultrafiltration of skim milks heated to different temperatures. Int. Dairy J. 6:581-596. http://dx.doi.org/10.1016/0958-6946(95)00061-5.

Hammershøj, M., A. B. Hougaard, J. S. Vestergaard, O. Poulsen, and R. H. Ipsen. 2010. Instant infusion pasteurisation of bovine milk. II. Effects on indigenous milk enzymes activity and whey protein denaturation. Int. J. Dairy Technol. 63:197-208. http://dx.doi. org/10.1111/j.1471-0307.2010.00583.x.

Horne, D. S. 2008. Chapter 5-Casein micelle structure and stability. Pages 133-162 in Milk Proteins. A. Thompson, M. Boland, and H. Singh, ed. Acad. Press, San Diego, CA.

Hougaard, A. B., M. Hammersh $ø$ j, J. S. Vestergaard, O. Poulsen, and R. H. Ipsen. 2009. Instant infusion pasteurisation of bovine milk. I. Effects on bacterial inactivation and physical-chemical properties. Int. J. Dairy Technol. 62:484-492. http://dx.doi.org/10.1111/ j.1471-0307.2009.00529.x.

Jensen, H. B., J. W. Holland, N. A. Poulsen, and L. B. Larsen. 2012. Milk protein genetic variants and isoforms identified in bovine milk representing extremes in coagulation properties. J. Dairy Sci. 95:2891-2903. http://dx.doi.org/10.3168/jds.2012-5346.

Jõudu, I., M. Henno, T. Kaart, T. Püssa, and O. Kärt. 2008. The effect of milk protein contents on the rennet coagulation properties of milk from individual dairy cows. Int. Dairy J. 18:964-967. http://dx.doi.org/10.1016/j.idairyj.2008.02.002.

Kessler, H.-G., and H.-J. Beyer. 1991. Thermal denaturation of whey proteins and its effect in dairy technology. Int. J. Biol. Macromol. 13:165-173. http://dx.doi.org/10.1016/0141-8130(91)90043-T.

Kontopidis, G., C. Holt, and L. Sawyer. 2004. Invited review: $\beta$-Lactoglobulin: Binding properties, structure, and function. J. Dairy Sci. 87:785-796. http://dx.doi.org/10.3168/jds.S00220302(04)73222-1.

Larsen, L., A. Wedholm-Pallas, H. Lindmark-Månsson, and A. Andrén. 2010. Different proteomic profiles of sweet whey and rennet casein obtained after preparation from raw versus heat-treated skimmed milk. Dairy Sci. Technol. 90:641-656. http://dx.doi. org $/ 10.1051 /$ dst $/ 2010024$.

Lewis, M. J., and H. C. Deeth. 2008. Heat treatment of milk. Pages 168-204 in Milk Processing and Quality Management. A. Y. Tamime, ed. Wiley-Blackwell, Hoboken, NJ.

Lorenzen, P. C., I. Clawin-Rädecker, K. Einhoff, P. Hammer, R. Hartmann, W. Hoffmann, D. Martin, J. Molketin, H. G. Walte, and M. Deverse. 2011. A survey of the quality of extended shelf life (ESL) milk in relation to HTST and UHT milk. Int. J. Dairy Technol. 64:166-178. http://dx.doi.org/10.1111/j.1471-0307.2010.00656.x.
Mann, M., and O. N. Jensen. 2003. Proteomic analysis of post-translational modifications. Nat. Biotechnol. 21:255-261. http://dx.doi. org/10.1038/nbt0303-255.

Martinez-Castro, I., A. Olano, and N. Corzo. 1986. Modifications and interactions of lactose with mineral components of milk during heating processes. Food Chem. 21:211-221. http://dx.doi. org/10.1016/0308-8146(86)90019-1

McDonald, W. H., R. Ohi, D. T. Miyamoto, T. J. Mitchison, and J. R. Yates III. 2002. Comparison of three directly coupled HPLC MS/MS strategies for identification of proteins from complex mixtures: Single-dimension LC-MS/MS, 2-phase MudPIT, and 3-phase MudPIT. Struct. Biol. Mol. 219:245-251. http://dx.doi. org/10.1016/S1387-3806(02)00563-8.

Mohammad, K. S., and P. F. Fox. 1987. Heat-induced microstructural changes in casein micelles before and after heat coagulation. N.Z. J. Dairy Sci. Tech. 22:191-203.

O'Connell, J., and P. F. Fox. 2003. Heat-induced coagulation of milk. Pages 879-945 in Advanced Dairy Chemistry. Vol. 1, Proteins. 3rd ed. P. F. Fox and P. McSweeney, ed. Kluwer Acad./Plenum Publ., New York, NY.

O'Connell, J. E., and P. F. Fox. 2011. Heat treatment of milk: Heat stability of milk. Pages 744-749 in Encyclopedia of Dairy Sciences. 2nd ed. J. W. Fuquay, ed. Acad. Press, San Diego, CA.

Oldfield, D. J., H. Singh, and M. W. Taylor. 1998a. Association of $\beta$-lactoglobulin and $\alpha$-lactalbumin with the casein micelles in skim milk heated in an ultra-high temperature plant. Int. Dairy J. 8:765-770. http://dx.doi.org/10.1016/S0958-6946(98)00127-7.

Oldfield, D. J., H. Singh, M. W. Taylor, and K. N. Pearce. 1998b. Kinetics of denaturation and aggregation of whey proteins in skim milk heated in an ultra-high temperature (UHT) pilot plant. Int. Dairy J. 8:311-318. http://dx.doi.org/10.1016/S0958-6946(98)00089-2.

Pierre, A., J. Frauquant, Y. Le Gaët, M. Poit, and J. L. Maubois. 1992. Préparation de phosphocaséinate natif par microfiltration sur membrane. Lait 72:461-474.

Poulsen, N. A., A. J. Buitenhuis, and L. B. Larsen. 2015. Phenotypic and genetic associations of milk traits with milk coagulation properties. J. Dairy Sci. 98:2079-2087. http://dx.doi.org/10.3168/ jds.2014-7944.

Rabilloud, T., M. Chevallet, S. Luche, and C. Lelong. 2010. Twodimensional gel electrophoresis in proteomics: Past, present and future. J. Proteomics 73:2064-2077. http://dx.doi.org/10.1016/j. jprot.2010.05.016

Rauh, V. M. 2014. Impact of plasmin activity on the shelf life and stability of UHT milk. PhD Thesis. Dept. Food Sci., Aarhus Univ., Aarhus, Denmark.

Rauh, V. M., L. B. Johansen, R. Ipsen, M. Paulsson, L. B. Larsen, and M. Hammershøj. 2014. Plasmin activity in UHT milk: Relationship between proteolysis, age gelation, and bitterness. J. Agric Food Chem. 62:6852-6860. http://dx.doi.org/10.1021/jf502088u.

Sauer, A., and C. I. Moraru. 2012. Heat stability of micellar casein concentrates as affected by temperature and $\mathrm{pH}$. J. Dairy Sci. 95:6339-6350. http://dx.doi.org/10.3168/jds.2012-5706.

Schokker, E. P., H. Singh, and L. K. Creamer. 2000. Heat-induced aggregation of $\beta$-lactoglobulin A and B with $\alpha$-lactalbumin. Int. Dairy J. 10:843-853. http://dx.doi.org/10.1016/S0958-6946(01)00022-X.

Singh, H., and P. Havea. 2003. Thermal denaturation, aggregation and gelation of whey proteins. Pages 1261-1287 in Advanced Dairy Chemistry. Vol. 1, Proteins. 3rd ed. P. F. Fox and P. L. H. McSweeney, ed. Kluwer Acad./Plenum Publ., New York, NY.

Singh, H., and J. M. Latham. 1993. Heat stability of milk: Aggregation and dissociation of protein at ultra-high temperatures. Int. Dairy J. 3:225-237. http://dx.doi.org/10.1016/0958-6946(93)90066-9.

Tolkach, A., and U. Kulozik. 2007. Reaction kinetic pathway of reversible and irreversible thermal denaturation of beta-lactoglobulin. Lait 87:301-315. http://dx.doi.org/10.1051/lait:2007012.

Tran Le, T., P. Saveyn, H. D. Hoa, and P. Van der Meeren. 2008. Determination of heat-induced effects on the particle size distribution of casein micelles by dynamic light scattering and nanoparticle tracking analysis. Int. Dairy J. 18:1090-1096. http://dx.doi. org/10.1016/j.idairyj.2008.06.006. 
Turner, L. G., H. E. Swaisgood, and A. P. Hansen. 1978. Interaction of lactose and proteins of skim milk during ultra-high-temperature processing. J. Dairy Sci. 61:384-392. http://dx.doi.org/10.3168/ jds.S0022-0302(78)83611-X.

van Boekel, M. A. J. S. 1998. Effect of heating on Maillard reactions in milk. Food Chem. 62:403-414. http://dx.doi.org/10.1016/S03088146(98)00075-2.

Walstra, P., T. J. Geurts, A. Noomen, A. Jellema, and M. A. J. S. van Boekel. 1999. Dairy Technology: Principles of Milk Properties and Processes. Marcel Dekker Inc., New York, NY.

Wang, Q., S. Bulca, and U. Kulozik. 2007. A comparison of low-intensity ultrasound and oscillating rheology to assess the renneting properties of casein solutions after UHT heat pre-treatment. Int. Dairy J. 17:50-58. http://dx.doi.org/10.1016/j.idairyj.2005.12.008.

Wang, Q., A. Tolkach, and U. Kulozik. 2006. Quantitative assessment of thermal denaturation of bovine $\alpha$-lactalbumin via low-intensity ultrasound, HPLC, and DSC. J. Agric. Food Chem. 54:6501-6506. http://dx.doi.org/10.1021/jf060895k

Waungana, A., H. Singh, and R. J. Bennett. 1996. Influence of denaturation and aggregation of $\beta$-lactoglobulin on rennet coagula- tion properties of skim milk and ultrafiltered milk. Food Res. Int. 29:715-721. http://dx.doi.org/10.1016/S0963-9969(97)00011-2.

Wedholm, A., L. B. Larsen, H. Lindmark-Månsson, A. H. Karlsson, and A. Andrén. 2006. Effect of protein composition on the cheese-making properties of milk from individual dairy cows. J. Dairy Sci. 89:3296-3305. http://dx.doi.org/10.3168/jds.S00220302(06)72366-9.

Wedholm, A., H. S. Møller, A. Stensballe, H. Lindmark-Månsson, A. H. Karlsson, R. Andersson, A. Andrén, and L. B. Larsen. 2008. Effect of minor milk proteins in chymosin separated whey and casein fractions on cheese yield as determined by proteomics and multivariate data analysis. J. Dairy Sci. 91:3787-3797. http://dx.doi. org/10.3168/jds.2008-1022.

Zúñiga, R. N., A. Tolkach, U. Kulozik, and J. M. Aguilera. 2010. Kinetics of formation and physicochemical characterization of thermally-induced $\beta$-lactoglobulin aggregates. J. Food Sci. 75:E261E268. http://dx.doi.org/10.1111/j.1750-3841.2010.01617.x. 